\title{
Influence of Victim and Perpetrators' Alcohol Use on Social Work Student's Levels of Rape Myth Acceptance
}

\author{
Adrienne Baldwin-White \\ Nada Elias-Lambert
}

\begin{abstract}
Rape myths are stereotyped, false cultural values that serve to justify sexual assault against women. This study examined the perceptions of alcohol use on levels of rape myth acceptance among social work students. One hundred and ninety-five bachelor's and master's students were randomly assigned to read a vignette developed by researchers depicting a date rape with the victim, perpetrator, both, or neither consuming alcohol. Results of a descriptive analysis showed that students are willing to accept certain rapesupportive beliefs, but not others. Participant responses to rape myths differed based on the particular vignette the respondent was assigned to read. Further research is needed to examine the particular myths social work students endorse and the situational factors that influence those endorsements. Social work students must be educated about how endorsements of rape myths can affect their interaction with survivors and perpetrators.
\end{abstract}

Keywords: Rape myth acceptance; rape supportive beliefs; social work students; sexual assault; alcohol consumption

Sexual assault is legally defined as any sexual contact or behavior that occurs without the explicit consent of the recipient. Behaviors considered sexual assault include activities such as forced sexual intercourse, fondling, and attempted rape (U.S. Department of Justice [DOJ], 2014c). Sexual assault is a public safety concern, with the U.S. Department of Justice (2014a) reporting an estimated 300,170 sexual assaults of persons age 12 and older in 2013. Approximately $91 \%$ of all sexual assault victims are women (U.S. DOJ, 2013). Sexual assault has implications for public and individual health, with long-term physical and mental health consequences (National Institute of Justice, 2007). Four out of five sexual assault victims suffer from a chronic physical or psychological condition, and are 13 times more likely to commit suicide than those who have never been victimized (National Institute of Justice, 2007). Rape, a form of sexual assault, is defined as the penetration, no matter how slight, of the vagina or anus with any body part or object, or oral penetration by a sex organ of another person, without the consent of the victim (DOJ, 2014c). Women who survive rape report high rates of depression, anxiety, post-traumatic stress disorder (Yuan, Koss \& Stone, 2006), sexual dysfunction (Postma, Bicanic, Vaart, \& Laan, 2013), issues with social adjustment (Hayes, Lorenz, \& Bell, 2013), and negative effects on self-esteem (Perilloux, Duntley \& Buss, 2012) and health (Zinzow et al., 2011).

Recent research has revealed that college students are at a high risk for sexual assault (Crawford, Wright, \& Birchmeier, 2008; Vanderwoerd, 2009) with the rate of sexual assault for college-age women $20 \%$ higher than for 18 to 24 year olds not enrolled in an institute of higher education (U.S. DOJ, 2014b). Twenty to twenty-five percent of collegeage women report a sexual assault while attending college (White House Council on

Adrienne Baldwin-White, MSW is a Doctoral Candidate, School of Social Work, Arizona State University, Phoenix, AZ 85004. Nada Elias-Lambert, PhD, LMSW is an Assistant Professor and MSW Program Coordinator, Department of Social Work, Texas Christian University, Fort Worth, TX 76129. 
Women and Girls, 2014) and are more likely to be sexually assaulted than any other age group (National Institute of Justice, 2000). College-age men have the greatest likelihood to commit sexual assault compared to any other age group. Thirty-five percent of collegeage men reported some proclivity towards sexual assault if they could be assured they would not get caught, and $23 \%$ reported committing acts that meet the definition of rape (Burgess, 2007).

The prevalence of sexual assault among female college students is influenced by the acceptance of rape myths (Chiroro, Bohner, Viki \& Jarvis, 2004). Rape myths are prejudicial or false beliefs about rape, rape victims, and rapists (Burt, 1980). Over half of college students endorse some combination of rape myths (Edwards, Turchik, Dardis, Reynolds, \& Gidycz, 2011). College students still possess scripts that are more conducive to what has been termed and described as "real rape" (Estrich, 1987; Ryan, 2011). A real rape is a false conceptualization of sexual assault that perpetuates the myth that a sexual assault involves a stranger and occurs late at night in a dark alley (Estrich, 1987). This real rape archetype is typically violent: the assailant uses a weapon and the victim has scars and bruises from attempting to fight off the perpetrator. In this real rape scenario, the victim also reports the incident immediately (Estrich, 1987).

Rape is a social problem and does not occur in social or cultural isolation (Campbell, Dworkin \& Cabral, 2009). For decades research has demonstrated that rape culture supports and condones objectifying, assaulting, and abusing women (Burt, 1980; Lonsway \& Fitzgerald, 1994; Shin, 2005; Walsh, 2015). Ward (1995) asserts that sexual assault and rape are a means to oppress women. The current patriarchal society perpetuates certain behavioral scripts, placing the responsibility on women to prevent an assault by conforming to expectations (Cahill, 2001). A woman's behaviors, therefore, are restrained out of the fear of sexual violence (Ward, 1995). Rape myths are an extension of this rape culture and are a complex set of cultural beliefs that perpetuate and support male violence against women (Aronowitz, Lambert, \& Davidoff, 2012). Rape myths are based on patriarchal social norms that potentially serve to dominate women through the threat of sexual assault. They serve to deny and justify the patriarchal violence of male sexual aggression and rape (Anderson, Beattie, \& Spencer, 2001).

One concept to emerge from the acceptance of the real rape scenario is the acceptance and prevalence of rape myths. Previous studies have demonstrated that college students are discriminant in their endorsement of rape myths; they accept certain rape myths and not others (McMahon, 2010). In order to reduce the prevalence of these myths, it is important to not only examine college students' overall levels of rape myth acceptance; research must also work to distinguish those myths that college students accept versus those they reject. It is also important to understand the factors that influence rape myth acceptance among social work students, particularly due to their potential to be an integral part in the implementation of sexual violence prevention programming and direct intervention with sexual assault survivors and perpetrators. Previous studies have explored the relationship between rape myth acceptance and circumstances such as a date rape or the consumption of alcohol among college students (Lonsway \& Fitzgerald, 1994). The current study sought to understand rape myth acceptance specifically among social work students by exploring 
how situational factors (date rape and alcohol consumption) affect which rape myths they are more likely to accept.

\section{Literature Review}

\section{Rape Myth Acceptance}

Rape myths support cultural values and ideas that justify the sexual victimization of women (King \& Roberts, 2011) and contribute to the public consciousness in unproductive and damaging ways (Kahlor \& Morrison, 2007). Rape myths also advocate that women should accept responsibility for their sexual victimization (Deming, Covan, Swan, \& Billings, 2013) by suggesting that women provoke their own sexual assault by the clothing they wear, their demeanor, being alone, being out at night or drinking. Rape myths have been called, "the most self-serving justification of sexual coercion ever invented by callous men" (Zillmann \& Weaver, 1989, p. 124). Common myths tend to blame the victim, exonerate the perpetrator, and deny or belittle the violence inherent in rape (Bohner, Siebler, \& Schmelcher, 2006).

Rape myth acceptance has the potential to facilitate sexual aggression by allowing men to turn off social prohibitions against committing sexual violence against women. Higher levels of rape myth acceptance have been linked to increased likelihood of sexual aggression (Basow \& Minieri, 2011). Higher levels of rape myth acceptance also have the potential to lead to the underreporting of sexual assaults (Heath, Lynch, Fritch, \& Wong, 2013). Women who accept these rape-supportive beliefs and whose experience corresponds with these myths are less likely to identify their experience as rape (Peterson \& Muehlenhard, 2004). Women who internalize these rape myths and blame themselves for the incident are more likely to have poor psychological well-being, including higher levels of depression and lower levels of self-esteem (Branscombe, Wohl, Owen, Allison, \& N'gbala, 2003).

\section{Situational Factors}

Date rape. Studies have shown that rape-supportive beliefs are applied to date rape, a rape by someone the victim knows (Estrich, 1987), more than to stranger rape (Bridges, 1991; Grubb \& Harrower, 2008). The majority of sexual assaults committed by college men occur on formal or casual dates or during interactions at parties (Abbey, McAuslan, Zawacki, Clinton, \& Buck, 2001). Eighty-five to ninety percent of sexual assault victims know their offender (National Institute of Justice, 2008). Date rape is considered less distressing (Heath et al., 2013), and observers are less likely to label forced sex with an acquaintance or date as rape (Bridges, 1991). Victims tend to be blamed more in incidents of date rape (Bridges, 1991; Hinck \& Thomas, 1999) with women being held responsible for not maintaining control of the situation and the man's behavior being mislabeled as a simple miscommunication or misunderstanding of sexual cues (Bridges, 1991). Date rape incidents are also more likely to involve the consumption of alcohol (Finch \& Munro, 2007). 
Alcohol consumption. Alcohol is a significant factor in the commission of sexual assault (Bernat, Calhoun, \& Stolp, 1998) and can be viewed as both a precipitant of and excuse for sexually aggressive behavior (Finch \& Munro, 2007). Sexual assault with voluntary alcohol consumption is the most common type of rape on college campuses with previous studies finding that sexual assault is more likely to occur among college students when one or both parties have been consuming alcohol (Lawyer, Resnick, Bakanic, Burkett, \& Kilpatrick, 2010). Forty percent of victims report they believed the offender was drinking prior to the victimization (U.S. Department of Justice, 2011). Alcohol consumption is a situational factor that has the potential to affect levels of rape myth acceptance (Bernat et al., 1998). A double standard exists among college students wherein perpetrators are held less responsible when consuming alcohol and victims are held more responsible when drinking (Finch \& Munro, 2007). Victims are more likely to blame themselves when they have been drinking alcohol and subsequently, may not report the assault (Hayes-Smith \& Levett, 2010).

\section{Sexual Assault and Social Work}

Sexual assault is an under-studied area in social work (McMahon \& Schwartz, 2011). However, research around intimate partner violence supports that in the past, the social work profession earned a reputation as uncaring, uninformed, and unhelpful to battered women. Social workers were faulted for blaming the victim, failing to recognize abuse as a problem, and failing to make appropriate interventions and referrals (Danis, 2003). Currently, social workers play a part in both prevention and intervention in sexual violence situations. Social workers develop and implement prevention programming to reduce sexual violence. They also provide treatment for clients who have experienced trauma due to sexual violence, as well as work with perpetrators who commit sexual assault.

Social work knowledge is essential to understanding the complexity of sexual assault and the multiple variables, including rape myth acceptance, that need to be addressed in effective prevention and intervention programming. In order to more fully understand the nuances of sexual assault, it is imperative that social work students understand how rape myth acceptance affects a woman's psychological and emotional state prior to and after experiencing a sexual assault. It is also important for social workers to understand a man's proclivity towards sexually aggressive behavior, how these myths may affect a woman's willingness to report the assault, and how the internalization of these myths may influence mental health outcomes during treatment.

Previous research has established that certain factors such as date or acquaintance rape (Heath et al., 2013) and alcohol consumption by the victim and/or perpetrator (Bernat et al., 1998) independently affect rape myth acceptance among observers. However, the current study sought to further understand the nuances of rape myth acceptance among social work students. The study examined the potential relationship between alcohol consumption, date rape, and a willingness to accept rape myths by presenting students with a hypothetical scenario depicting a date rape involving alcohol consumption by the victim, perpetrator, both victim and perpetrator, or neither victim nor perpetrator. No studies known to the authors have been conducted to examine whether these perceptions affect the rape-supportive beliefs an individual attributes to a particular incident of rape. 


\section{Methods}

This descriptive study used a cross-sectional survey design to assess the differences in responses across four date rape vignettes involving alcohol consumption. A descriptive methodology was used because previous research has demonstrated that college students have low overall levels of rape myth acceptance; however, more discriminant analysis has demonstrated that college students are more willing to accept some myths (Gerger, Kley, Bohner, \& Siebler, 2007). Therefore, a descriptive analysis has the potential to identify which myths college students are more willing to accept and how situational factors influence those tendencies. A descriptive analysis provides the necessary foundation for understanding what rape-supportive beliefs social work students endorse. This study also implements a vignette methodology that the researchers have not found in other research concerning rape myth acceptance and provides an important foundation for future analyses. The use of varied vignettes may reveal social work students' rape-supportive beliefs and whether those beliefs vary with different alcohol consumption scenarios.

\section{Participants}

A convenience sample of 197 bachelor's and master's social work students completed the survey. As shown in Table 1, a majority of respondents self-identified as female (84\%) and White/Caucasian (61\%). The majority of respondents $(69 \%)$ were graduate students with a mean age of 29 .

Table 1. Respondents Demographics $(n=197)$

\begin{tabular}{llll}
\hline Label & Label & $\underline{\mathrm{n}}$ & $\underline{\%}$ \\
\hline Gender & Female & 166 & 84.3 \\
& Male & 31 & 15.7 \\
Race/Ethnicity & White/Caucasian & 121 & 61.4 \\
& Black/African American & 10 & 5.1 \\
& Hispanic/Latino & 39 & 19.8 \\
& Asian & 3 & 1.5 \\
& Native American & 8 & 4.1 \\
& Pacific Islander & 0 & 0 \\
& Mixed Race & 11 & 5.6 \\
Oge & Other & 4 & 2.0 \\
& 18-22 & 34 & 17.3 \\
& 23-25 & 58 & 29.4 \\
& 26-30 & 37 & 18.8 \\
& $31-62$ & 68 & 34.5 \\
Education Level & Undergraduate & 61 & 31 \\
& Graduate & 136 & 69 \\
\hline
\end{tabular}

\section{Procedure}

Participants were recruited by contacting all social work instructors in the same department as the primary author at a southwestern university via email. They were asked 
if they would be willing to distribute a link to an anonymous survey or allow facilitation of the survey in their classroom. The instructors were informed that the purpose of the research was to examine perceptions of rape among social work students. Twenty-six professors or instructors were contacted. After receiving responses from 23 instructors, each class was randomly assigned to one of the four different conditions with the following number of social work students in each condition: victim drinking $(n=52)$, perpetrator drinking $(n=54)$, both drinking $(n=35)$, and neither drinking $(n=54)$. The survey was not administered in-person to any students in the authors' classes; however, it is possible that students in the authors' classes completed the online survey. Students did not receive incentives for completing the survey. Students were advised that by completing the anonymous survey, they were providing consent. For those students completing the survey online, a study description, along with the link, was forwarded to instructors who then sent the link to their students. After two weeks, a reminder was sent to instructors encouraging students to complete the survey. The survey remained available online for one month. The study received university Institutional Review Board approval.

The survey included a vignette describing a sexual assault. The vignette for this study was developed using a template from a previous vignette study that had been created for sexual assault research; the researchers created the template by defining and identifying significant elements that should be included in a study that uses a vignette describing a sexual assault (Crawford et al., 2008). The authors then used that example as a foundation while incorporating elements relevant to this particular study, such as the inclusion of alcohol and the description of a date rape. The participants were asked to read the vignette and respond to the survey questions based on the situation described in the vignette. Prior research suggests that in order to ensure vignette equivalency, all descriptions of the scenarios should be the same except for the factor being measured (Rice, Robone, \& Smith, 2011). Therefore, each aspect of the four vignettes was the same except for the drinking component: the first vignette described a sexual assault with only the victim, Audrey, drinking (Vignette 1); the second vignette described a sexual assault with only the perpetrator, Joshua, drinking (Vignette 2); the third vignette described a sexual assault with both the victim and perpetrator drinking (Vignette 3); the fourth vignette described a sexual assault with neither the victim nor perpetrator drinking (Vignette 4).

The following is Vignette 1 which describes a sexual assault with only the victim, Audrey, drinking.

Audrey was invited by her friends to attend a fraternity party on her college campus. Audrey was excited to go and spent the entire afternoon picking an outfit, deciding on her favorite strapless little black dress and 4 inch heels. She had spent the entire week studying non-stop for midterms and was ready to have a little fun. She was even more excited to find out that Joshua was going. Joshua had taken her out on a few dates; taking her to a concert, dinner, a picnic in the park and the movies; and they had been intimate. They really liked each other. When they arrive at the party, Audrey and her friends grab a beer. They dance, talk and have a good time. Audrey immediately goes to Joshua when she sees him walk through the door. They kiss and hug each other. They spend the rest of the party talking, kissing and flirting. Audrey continues to drink throughout the party. At the end of the night 
Audrey invites Joshua back to her room. She is feeling slightly intoxicated and since Joshua has only had soft drinks the entire night, he drives her to her dorm so she doesn't have to walk. When they arrive at Audrey's room, they begin to kiss. Joshua is assertive and pushes her down on the bed. Audrey says she doesn't want to because she is feeling sick but Joshua persists. He tells her it's not a big deal because they had sex before but Audrey insists and tells him she doesn't want to. Joshua gets on top of her and she tries to push him off. She continues to tell him "no" but he doesn't stop. After a couple of minutes of trying to push him off and telling him no, she puts her head to the side and closes her eyes. After Joshua finishes, he kisses her on the lips gently and puts on his clothes. He tells her he will call her tomorrow and leaves. Audrey sits up and checks her body to see if she has any bruises. After not seeing any physical injuries, she turns off her cell phone, lays down and tries to go to sleep.

As previously mentioned, the only differences between the vignettes was who was drinking alcohol - the victim (Audrey), the perpetrator (Joshua), both victim and perpetrator, or neither. Vignette 2 portrayed Audrey drinking only soda throughout the night in order to be the designated driver and indicated that she drove herself, her friends, and Joshua back to the dorm. Vignette 3 indicated that both Audrey and Joshua were drinking alcohol and both walked back to the dorm instead of driving. Lastly, Vignette 4 described both Audrey and Joshua abstaining from alcohol consumption. The last vignette also indicated that Audrey drove herself, her friends, and Joshua back to the dorm.

\section{Measures}

In order to gather basic background information, students were asked demographic questions, including age, gender, race/ethnicity, and education level (see Table 1).

\section{Vignette Scale}

After reading the vignette, respondents were asked to respond to 10 survey items pertaining directly to each of the vignettes. Each item addressed a specific rape myth (see Table 2) and addressed typical rape myths related to the vignettes. For example, "Because they previously had sex, it is okay that Joshua expected to have sex with Audrey." Answer options for each item were: agree, disagree, or uncertain. Ten of the items were common across all surveys. For three of the four vignettes, there were unique items that pertained specifically to the scenario presented in the vignette. For example, in vignette one with Audrey drinking, participants were asked if Audrey, the victim, could consent to having sex with Joshua. This item would not have been relevant in the vignettes describing Joshua drinking or neither person drinking. For those who read the vignette with Audrey drinking, items were included such as, "Audrey should not have taken Joshua to her room considering her intoxicated state." For those who read the vignette with Joshua drinking, items such as "Joshua didn't fully understand what he was doing because he had been drinking," were included. For those who read the vignette with both Audrey and Joshua drinking, items such as "Because of their intoxicated states, Audrey should have expected Joshua would want to have sex" were included. These items were used to evaluate students' responses to the specific scenario. 
Table 2. Vignette Statements and the Rape Myths They Represent

\begin{tabular}{|l|l|}
\hline \multicolumn{1}{|c|}{ Vignette Item } & \multicolumn{1}{c|}{ Rape Myth } \\
\hline $\begin{array}{l}\text { Audrey's outfit gave Joshua the wrong impression } \\
\text { and led him to be sexually aggressive. }\end{array}$ & $\begin{array}{l}\text { Women who dress provocatively are responsible for } \\
\text { a sexual assault. }\end{array}$ \\
\hline $\begin{array}{l}\text { Audrey's flirtatious behavior led Joshua on, giving } \\
\text { him the impression that sexual advances would be } \\
\text { expected. }\end{array}$ & $\begin{array}{l}\text { If a woman is flirtatious, she should expect a partner } \\
\text { would want sex and be held accountable if a sexual } \\
\text { assault occurs. }\end{array}$ \\
\hline $\begin{array}{l}\text { Because they had previously had sex, it is okay that } \\
\text { Joshua expected to have sex with Audrey. }\end{array}$ & $\begin{array}{l}\text { If a woman consents to having sex with a partner } \\
\text { one time, then it is assumed that she will consent to } \\
\text { having sex with that partner all the time. }\end{array}$ \\
\hline $\begin{array}{l}\text { Because Audrey invited Joshua back to her room, she } \\
\text { should have expected that he would want to have sex } \\
\text { with her. }\end{array}$ & $\begin{array}{l}\text { If a woman invites a partner back to her room, she is } \\
\text { accountable if a sexual assault occurs. }\end{array}$ \\
\hline $\begin{array}{l}\text { Even though Audrey said no, because she stopped } \\
\text { fighting him, she consented to having sex. }\end{array}$ & $\begin{array}{l}\text { A woman is required to fight vigorously to protect } \\
\text { herself against a perpetrator attempting to sexually } \\
\text { assault her. }\end{array}$ \\
\hline $\begin{array}{l}\text { Because Joshua kissed Audrey and told her he would } \\
\text { call, he is a good boyfriend. }\end{array}$ & $\begin{array}{l}\text { Rape is just bad sex; or men who commit sexual } \\
\text { assaults just made a mistake and are not bad men. }\end{array}$ \\
\hline $\begin{array}{l}\text { Even though Audrey may be upset right now, } \\
\text { everything will be better tomorrow. }\end{array}$ & $\begin{array}{l}\text { Rape does not have substantial negative effects on } \\
\text { victims. }\end{array}$ \\
\hline $\begin{array}{l}\text { Because Audrey did not have any physical injuries, } \\
\text { Joshua was not too sexually aggressive. }\end{array}$ & $\begin{array}{l}\text { A woman who is sexually assaulted will always } \\
\text { have physical injuries. }\end{array}$ \\
\hline This is an example of a sexual assault. & $\begin{array}{l}\text { Rape is more serious than sexual assault; rape has } \\
\text { more devastating effects than sexual assault. }\end{array}$ \\
\hline $\begin{array}{l}\text { This is an example of rape. } \\
\text { unless force was used to have sex with a woman. }\end{array}$ \\
\hline
\end{tabular}

\section{Data Analysis}

Descriptive analyses were performed to assess the differences in responses across the four date rape vignettes and examine the impact of the particular vignette respondents read on social work students' rape-supportive beliefs.

\section{Results}

Four items on the vignette scale had a similar percentage of respondents across all four groups: "Because they had previously had sex, it is okay that Joshua expected to have sex with Audrey," "Even though Audrey said no, because she stopped fighting him, she consented to having sex," "Even though Audrey may be upset right now, everything will be better tomorrow," and "Because Audrey did not have any physical injuries, Joshua was not too sexually aggressive." For the other six items, the vignette each respondent read had a significant impact on results, with a variation in responses between groups (see Table 3 ). For example, $21 \%$ of respondents who read the vignette with Audrey drinking agreed that she should have expected Joshua would want to have sex considering she invited him back to her room; only $8 \%$ of those who read the vignette with Joshua drinking agreed. Twentyone percent of respondents who read the vignette with neither drinking agreed that Audrey led Joshua on with her flirtatious behavior, leading to the sexual assault; however, only 5\% of those who read the vignette with Joshua drinking agreed that Audrey held some responsibility for leading Joshua on by flirting with him. Ninety-seven percent of participants who read the vignette with Joshua drinking thought the incident was an example of sexual assault; only $52 \%$ believed the incident was an example of rape. 
Table 3. Descriptive Statistics: Vignette Scale $(n=197)$

\begin{tabular}{|c|c|c|c|c|c|c|c|c|c|c|c|c|}
\hline \multirow[b]{2}{*}{ Question } & \multicolumn{3}{|c|}{$\begin{array}{c}\text { Vignette } 1 \text { - } \\
\text { Audrey Drinking (n=52) }\end{array}$} & \multicolumn{3}{|c|}{$\begin{array}{c}\text { Vignette 2 - } \\
\text { Joshua Drinking }(\mathrm{n}=54)\end{array}$} & \multicolumn{3}{|c|}{$\begin{array}{c}\text { Vignette 3 - } \\
\text { Both Drinking }(n=35)\end{array}$} & \multicolumn{3}{|c|}{$\begin{array}{c}\text { Vignette } 4 \text { - } \\
\text { Neither Drinking }(n=54)\end{array}$} \\
\hline & $\mathbf{A}$ & D & $\mathbf{U}$ & A & D & $\mathbf{U}$ & $\mathbf{A}$ & D & $\mathbf{U}$ & A & D & $\mathbf{U}$ \\
\hline $\begin{array}{l}\text { Audrey's outfit gave Joshua the } \\
\text { wrong impression and led him to } \\
\text { be sexually aggressive. }\end{array}$ & $0(0 \%)$ & $53(98.1 \%)$ & $0(0 \%)$ & $27(45 \%)$ & $30(50 \%)$ & $2(3.3 \%)$ & $2(4.3 \%)$ & $31(85.1 \%)$ & $2(6.4 \%)$ & $1(1.5 \%)$ & $52(93.9 \%)$ & $2(3 \%)$ \\
\hline $\begin{array}{l}\text { Because they have previously had } \\
\text { sex, it is okay Joshua expected to } \\
\text { have sex with Audrey. }\end{array}$ & $3(6.1 \%)$ & $42(83.3 \%)$ & $3(6.1 \%)$ & $5(8.3 \%)$ & $51(86.7 \%)$ & $2(3.3 \%)$ & $2(6.4 \%)$ & $32(89.4 \%)$ & $0(0 \%)$ & $4(7.6 \%)$ & $49(89.4 \%)$ & $1(1.5 \%)$ \\
\hline $\begin{array}{l}\text { Audrey's flirtatious behavior led } \\
\text { Joshua on, giving him the } \\
\text { impression that sexual advances } \\
\text { would be expected. }\end{array}$ & $10(19.7 \%)$ & $32(63.6 \%)$ & $6(12.1 \%)$ & $3(5 \%)$ & $47(80 \%)$ & $8(13.3 \%)$ & $6(17 \%)$ & $21(59.6 \%)$ & $7(19.1 \%)$ & $12(21.3 \%)$ & $39(71.2 \%)$ & $3(6.1 \%)$ \\
\hline $\begin{array}{l}\text { Even though Audrey said no, } \\
\text { because she stopped fighting him, } \\
\text { she consented to having sex. }\end{array}$ & $0(0 \%)$ & $46(92.4 \%)$ & $1(1.5 \%)$ & $2(5 \%)$ & $54(91.7 \%)$ & $1(1.7 \%)$ & $1(2.1 \%)$ & $34(93.6 \%)$ & $0(0 \%)$ & $0(0 \%)$ & $53(95.5 \%)$ & $2(3 \%)$ \\
\hline $\begin{array}{l}\text { Because Audrey invited Joshua } \\
\text { back to her room, she should have } \\
\text { expected that he would want to } \\
\text { have sex with her. }\end{array}$ & $11(21.2 \%)$ & $32(63.6 \%)$ & $5(10.6 \%)$ & $5(8.3 \%)$ & $49(83.3 \%)$ & $4(6.7 \%)$ & $13(36.2 \%)$ & $21(58.9 \%)$ & $4(10.6 \%)$ & $17(30.3 \%)$ & $33(60.6 \%)$ & $4(7.6 \%)$ \\
\hline $\begin{array}{l}\text { Even though Audrey may be upset } \\
\text { right now, everything will be better } \\
\text { tomorrow. }\end{array}$ & $0(0 \%)$ & $48(93.9 \%)$ & $2(3 \%)$ & $0(0 \%)$ & $53(90 \%)$ & $5(8.3 \%)$ & $0(0 \%)$ & $30(83 \%)$ & $5(12.8 \%)$ & $0(0 \%)$ & $48(86.4 \%)$ & $7(12.1 \%)$ \\
\hline $\begin{array}{l}\text { Because Audrey did not have any } \\
\text { physical injuries, Joshua was not } \\
\text { too sexually aggressive. }\end{array}$ & $1(1.5 \%)$ & $48(93.9 \%)$ & $1(1.5 \%)$ & $0(0 \%)$ & $58(98.3 \%)$ & $0(0 \%)$ & $1(2.1 \%)$ & $31(87.2 \%)$ & $2(6.4 \%)$ & $1(1.5 \%)$ & $53(95.5 \%)$ & $1(1.5 \%)$ \\
\hline $\begin{array}{l}\text { Because Joshua kissed Audrey and } \\
\text { told her he would call, he is a good } \\
\text { boyfriend. }\end{array}$ & $0(0 \%)$ & $48(92.4 \%)$ & $2(3 \%)$ & $8(13.3 \%)$ & $40(68.3 \%)$ & $10(16.7 \%)$ & $0(0 \%)$ & $34(95.7 \%)$ & $0(0 \%)$ & $0(0 \%)$ & $53(95.5 \%)$ & $2(3 \%)$ \\
\hline $\begin{array}{l}\text { This is an example of sexual } \\
\text { assault. }\end{array}$ & $53(98.5 \%)$ & $0(0 \%)$ & $0(0 \%)$ & $57(96.7 \%)$ & $0(0 \%)$ & $1(1.7 \%)$ & $32(89.4 \%)$ & $1(2.1 \%)$ & $2(4.3 \%)$ & $53(97 \%)$ & $0(0 \%)$ & $1(1.5 \%)$ \\
\hline This is an example of rape. & $48(92.4 \%)$ & $0(0 \%)$ & $1(3 \%)$ & $31(51.7 \%)$ & $22(38.3 \%)$ & $5(8.3 \%)$ & $30(83 \%)$ & $1(2.1 \%)$ & $4(10.6 \%)$ & $49(89.4 \%)$ & $1(1.5 \%)$ & $4(7.6 \%)$ \\
\hline
\end{tabular}

Note- A-Agree, D-Disagree, U-Uncertain 


\section{Unique Vignette Questions}

\section{Vignette 1 - Audrey Drinking}

The respondents who read the vignette with Audrey drinking were asked unique questions pertaining specifically to the circumstances of that particular vignette (see Table 4). Forty-five percent of respondents believed that Audrey should not have taken Joshua back to her room considering her intoxicated state. Twenty-nine percent agreed that Audrey was able to consent to having sex even though she was intoxicated. Ninety-six percent of respondents believed Joshua took advantage of Audrey in her intoxicated state, and 88\% thought it was unreasonable to think that Joshua did not believe Audrey when she said no due to her intoxicated state.

Table 4. Unique Questions: Vignette 1 Audrey Drinking

\begin{tabular}{|c|c|c|c|}
\hline & Agree & Disagree & Uncertain \\
\hline $\begin{array}{l}\text { Even though Audrey was intoxicated, she was able } \\
\text { to consent to having sex with Joshua. }\end{array}$ & $18 \overline{(28.8 \%)}$ & $36(57.6 \%)$ & $6(9.2 \%)$ \\
\hline $\begin{array}{l}\text { Audrey should not have taken Joshua back to her } \\
\text { room considering her intoxicated state. }\end{array}$ & $29(45.5 \%)$ & $22(35.4 \%)$ & $9(13.8 \%)$ \\
\hline $\begin{array}{l}\text { It is reasonable to think that Joshua did not believe } \\
\text { Audrey when she said no because she had been } \\
\text { drinking. }\end{array}$ & $2(3.0 \%)$ & $55(87.9 \%)$ & $3(4.6 \%)$ \\
\hline $\begin{array}{l}\text { Joshua took advantage of Audrey in her intoxicated } \\
\text { state. }\end{array}$ & $61(95.5 \%)$ & $0(0 \%)$ & $1(1.5 \%)$ \\
\hline
\end{tabular}

Vignette 2 - Joshua Drinking

Participants who read Vignette 2 were asked to respond to items relevant to the circumstances of only Joshua drinking (see Table 5). For those who read Vignette 2, $97 \%$ did not excuse Joshua's sexually aggressive behavior because he was intoxicated and, ultimately, held Joshua responsible. However, 47\% agreed that, "Joshua didn't fully understand what he was doing because he had been drinking." The majority of respondents (72\%) did not hold Audrey responsible for the incident because she took him to her room. This contradicts results showing that $69 \%$ agreed he should have expected sex since she invited him to her room.

Table 5. Unique Questions: Vignette 2 Joshua Drinking

$\begin{array}{llll}\begin{array}{l}\text { Because Joshua was intoxicated, his sexually aggressive } \\ \text { behavior is excused. }\end{array} & \frac{\text { Agree }}{0(0 \%)} & \frac{\text { Disagree }}{54(96.7 \%)} & \frac{\text { Uncertain }}{1(1.7 \%)} \\ \begin{array}{l}\text { Audrey should not have taken Joshua to her room } \\ \text { considering his intoxicated state. }\end{array} & 7(11.7 \%) & 40(71.7 \%) & 8(15.0 \%) \\ \begin{array}{l}\text { Joshua didn't fully understand what he was doing } \\ \text { because he had been drinking. }\end{array} & 26(46.7 \%) & 21(36.7 \%) & 8(15.0 \%) \\ & & & \end{array}$

\section{Vignette 3 - Both Audrey and Joshua Drinking}

Respondents who read the vignette with both victim and perpetrator drinking were asked to respond to unique questions relevant to that vignette (see Table 6). Although 75\%

of those who read Vignette 3 did not believe Audrey should have expected Joshua would 
want to have sex considering their intoxicated states, $17 \%$ agreed, potentially excusing his behavior. In response to, "Audrey should not have taken Joshua to her room considering their intoxicated states," 68\% agreed. Thirty-eight percent of respondents believed Audrey was able to consent while $40 \%$ disagreed and $16 \%$ were uncertain. Eighty-three percent of respondents believed Joshua understood what he was doing despite his intoxicated state, and $85 \%$ believed Joshua took advantage of Audrey in her intoxicated state.

Table 6. Unique Questions: Vignette 3 Audrey and Joshua Drinking

\begin{tabular}{|c|c|c|c|}
\hline & Agree & Disagree & Uncertain \\
\hline $\begin{array}{l}\text { Because of their intoxicated states, Audrey should have } \\
\text { expected Joshua would want to have sex. }\end{array}$ & $6(\overline{17.0 \%})$ & $\overline{27(74.5 \%)}$ & $2(4.3 \%)$ \\
\hline $\begin{array}{l}\text { Audrey should not have taken Joshua to her room } \\
\text { considering their intoxicated states. }\end{array}$ & $25(68.1 \%)$ & $6(17.0 \%)$ & $4(10.6 \%)$ \\
\hline $\begin{array}{l}\text { Even though Audrey was intoxicated, she was able to } \\
\text { consent to having sex with Joshua. }\end{array}$ & $13(38.3 \%)$ & $14(40.4 \%)$ & $5(15.6 \%)$ \\
\hline $\begin{array}{l}\text { Joshua didn't fully understand what he was doing } \\
\text { because he had been drinking. }\end{array}$ & $2(4.3 \%)$ & $30(83.0 \%)$ & $3(8.9 \%)$ \\
\hline $\begin{array}{l}\text { Joshua took advantage of Audrey in her intoxicated } \\
\text { state. }\end{array}$ & $31(85.1 \%)$ & $2(4.3 \%)$ & $2.4(6.7 \%)$ \\
\hline
\end{tabular}

\section{Discussion}

Rape myth acceptance is an essential concept in the understanding of sexual assault and the ultimate reduction in the prevalence of rape among college students (Lonsway \& Fitzgerald, 1994). Therefore, it is important to understand levels of rape myth acceptance among social work students not only due to their own potential to perpetrate or be victims of sexual assault, but also because social work students are likely to interact with sexual assault survivors and perpetrators in practice settings. Previous research has shown that although college students have low levels of rape myth acceptance overall, they do accept certain rape myths while rejecting others (McMahon, 2010). The current study shows that certain factors, such as the consumption of alcohol or the relationship between the perpetrator and victim, may affect college students' willingness to support certain beliefs about rape.

Research suggests that males are more accepting of rape myths (Buddie \& Miller, 2001). In this study, because the majority of the sample was female, gender comparisons were not feasible. However, the results showed that female social work students endorse certain rape myths, such as if a woman has been drinking, she did something careless to put herself in that situation and bears some responsibility. These results are significant because they suggest that at least a portion of respondents have internalized these rape myths. Women who endorse rape myths are less likely to acknowledge an incident that meets the definition of sexual assault as rape, to report it, or to seek treatment due to their own shame and guilt (Duran, Moya, Megias, \& Viki, 2010). Even among social work students, there may be a portion of students who do not identify an incident as rape and therefore may not report the incident or seek help.

The authors proposed that the respondents' levels of rape myth acceptance would be influenced not only by alcohol consumption, in general, by those in the scenario, but also 
by which individual was drinking in the vignette. Overall, respondents endorsed certain rape myths while rejecting others, demonstrating low to moderate levels of rape myth acceptance. Results are consistent with previous research (Bridges, 1991) and reveal the double standard that exists in the relationship between gender and alcohol consumption. When the victim was drinking, she was held more responsible for the incident. However, when the perpetrator was consuming alcohol, he was held less responsible, and respondents were more likely to excuse his behavior. When the victim is sober, perhaps respondents believe she should have taken more precautions. Alcohol is also an important factor to consider when examining beliefs about rape because at least $50 \%$ of sexual assaults among college students involve alcohol consumption (Krebs, Lindquist, Warner, Fisher, \& Martin, 2007). Therefore, alcohol is a likely component that will influence how observers perceive a sexual assault. This study demonstrated that not only did alcohol consumption by the victim and/or perpetrator involved in a sexual assault affect a social work student's willingness to accept certain rape myths, but who was consuming alcohol also affected a participant's willingness to accept certain rape-supportive beliefs. Additionally, respondents were discriminatory in their rape myth acceptance, simultaneously holding the victim accountable for her drinking or flirtatious behaviors and holding the perpetrator responsible for his sexually aggressive behavior.

Results of the study also show that social work students may conceptualize sexual assault and rape differently. Respondents were first asked if the incident was a sexual assault; and then later, in a separate question, asked if the same incident was a rape. In all groups, a smaller percentage of respondents identified the incident as a rape compared to the percentage that identified the incident as a sexual assault, with the largest percentile difference in respondents who read the vignette with Joshua drinking. There could be multiple potential explanations for this difference. First, it is possible that the sample possesses real rape scripts. Because the described incident does not coincide with their ideas about what rape looks like, they do not believe the incident was rape. Secondly, because Joshua was drinking, perhaps respondents exhibited a double standard wherein because he was drinking, they did not believe he had committed rape. Alcohol, in this case, was an excuse for his behavior and absolved him of wrongdoing. Fourth, Joshua did not fit the real rape scenario of a rapist who is violent, aggressive, and uses a weapon; therefore, Joshua did something wrong, but was not necessarily a rapist. Social work students also appear to lack a clear understanding of consent. When reading the vignette with Audrey drinking, nearly half of the sample agreed the victim was able to consent to sex despite her intoxicated state.

\section{Implications for Social Work Education and Practice}

The results of this study are important because in order for sexual assault survivors to have the best potential outcomes while in treatment, social work students must be aware of and work to correct the biases they have towards survivors, perpetrators, and the act of rape. Social workers are typically more empathetic towards those in need (Acker, 1999); however, this study shows that even those learning to be helping professionals can have misunderstandings concerning the act of rape and the behaviors of perpetrators and survivors. These views could lead social workers to dismiss a victim's claim of sexual 
assault due to a lack of understanding of what constitutes a rape or sexual assault or due to subconscious biases that influence their interaction with victims. This could have tremendous negative effects on clients. Research suggests that survivors of sexual assault who are not believed by helping professionals, including social workers, tend to have poorer psychological or emotional outcomes (Ullman \& Peter-Hagene, 2014). In addition, social work students displayed the double standard that places more responsibility on the victim if she has been drinking and less responsibility on the perpetrator if he has been drinking. The study demonstrates it is important to understand this double standard because a social worker has the potential to behave differently if a survivor or perpetrator has been drinking alcohol due to changes in his/her perceptions of sexual assault. This perception may create a bias in interventions and may leave perpetrators without proper treatment because their behavior has been excused due to alcohol consumption or victims without the necessary support to help them move past the trauma of sexual assault.

Students demonstrated a less overt endorsement of rape myths by participating in both victim-blaming and exonerating the perpetrator but also holding the perpetrator accountable for his actions. This inconsistency is a potential reflection of the current limitations of social work education, which may benefit from being more inclusive of issues pertaining to the prevention of violence against women. Social work students need to be further educated concerning the nuances of sexual assault in order to be better advocates for survivors. Social work students must be educated about how endorsements of rape myths can affect their interaction with survivors and perpetrators.

This research demonstrates that these beliefs about rape cannot be understood in isolation and are influenced by social and environmental factors, such as the consumption of alcohol or the relationship between the survivor and perpetrator. Because these beliefs serve to oppress women (Ward, 1995), social work education should address these social constructs and work to change them among social work students to ensure the best possible treatment outcomes for women suffering from mental, emotional, and physical health issues due to the trauma of a sexual assault. Also, because social workers understand the importance of and examine the influence of socio-environmental factors, social work education can provide students with foundational knowledge about how the social construct of rape myths are created and maintained by certain belief systems.

In order for social workers to conduct effective prevention programming around the issue of sexual violence, social work students must understand the relationship between alcohol consumption and consent in date rape situations. Social workers who conduct prevention programming and also endorse rape myths may inadvertently exhibit rapesupportive values and beliefs when conducting prevention programming. This could be detrimental when attempting to change the beliefs that currently support sexually abusive behaviors. When conducting prevention programming, social workers will more than likely interact with both survivors and perpetrators. So, if those prevention programmers exhibit rape-supportive beliefs, survivors in attendance may feel blamed for the sexual assault they experienced, and perpetrators may feel justified in their actions to commit sexual violence. It is important for social workers who present prevention programs to understand the link between rape myth acceptance and alcohol consumption in order to effectively explain the 
relationship between situational circumstances and the acceptance of rape-supportive beliefs.

\section{Limitations and Future Research}

Selection bias may have an effect on results. Students who self-selected to participate in the study may be students who have low levels of rape myth acceptance. Social desirability is also a concern. Social work students may be more likely to answer in a way that is more socially acceptable; therefore, the results may not be a true reflection of what social work students believe. In addition, the study did not account for the influence of respondents' own experience with sexual assault.

Future research needs to include a larger sample of men to understand both gender differences and men's rape myth acceptance levels. Future research also needs to explore the potential differences in rape myth acceptance based on the gender of the participant, whether male or female; and explore whether male victims evoke more or less rape supportive beliefs. Also, studies need to examine rape supportive beliefs in the context of same-sex relationships. In-depth qualitative analyses should also be completed in order to provide more insight into what social work students, and college students in general, believe about rape and the factors that influence those beliefs. In order to have the largest impact on college students, future studies should also go beyond social work to include college students in other disciplines.

\section{Conclusion}

Understanding the different facets of rape myth acceptance is significant in order to not only reduce the negative effects of these myths on individuals and society as a whole, but also potentially reduce the prevalence of sexual assault. There is optimal opportunity within the social work curriculum to facilitate learning and discussion around sexual violence and rape myths in order to ensure that social work students are prepared to be effective practitioners when working with survivors and perpetrators of violence against women.

\section{References}

Abbey, A., McAuslan, P., Zawacki, T., Clinton, A.M., \& Buck, P. (2001). Attitudinal, experiential, and situational predictors of sexual assault perpetration. Journal of Interpersonal Violence, 16(8), 784-807. doi:http://dx.doi.org/10.1177/088626001016008004

Acker, G. M. (1999). The impact of clients' mental illness on social workers' job satisfaction and burnout. Health \& Social Work, 24(2), 112-119. doi:http://dx.doi.org/10.1093/hsw/24.2.112

Anderson, I., Beattie, G., \& Spencer, C. (2001). Can blaming victims of rape be logical?: Attribution theory and discourse analytic perspective. Human Relations, 54(4), 445467. doi:http://dx.doi.org/10.1177/0018726701544003 
Aronowitz, T., Lambert, C. A., \& Davidoff, S. (2012). The role of rape myth acceptance in the social norms regarding sexual behavior among college students. Journal of Community Health Nursing, 29(3), 173-182. doi:http://dx.doi.org/10.1080/07370016.2012.697852

Basow, S. A., \& Minieri, A. (2011). "You owe me": Effects of date cost, who pays, participant gender, and rape myth beliefs on perceptions of rape. Journal of Interpersonal Violence, 26, 479-497. doi:http://dx.doi.org/10.1177/0886260510363421

Bernat, J., Calhoun, K., \& Stolp, S. (1998). Sexually aggressive men's responses to a date rape analogue: Alcohol as disinhibiting cue. The Journal of Sex Research, 35(4), 334348. doi:http://dx.doi.org/10.1080/00224499809551952

Bohner, G., Siebler, F., \& Schmelcher, J. (2006). Social norms and the likelihood of raping: Perceived rape myth acceptance of others affects men's rape proclivity. Personal Psychology Bulletin, 32(3), 286-297. doi:http://dx.doi.org/10.1177/0146167205280912

Branscombe, N., Wohl, M., Owen, S., Allison, J., \& N'gbala, A. (2003). Counterfactual thinking, blame assignment, and well-being in rape victims. Basic and Applied Social Psychology, 25(4), 265-273. doi:http://dx.doi.org/10.1207/S15324834BASP2504_1

Bridges, J. (1991). Perceptions of date and stranger rape: A difference in sex role expectations and rape-supportive beliefs. Sex Roles, 24(5.6), 291-307. doi:http://dx.doi.org/10.1007/BF00288303

Buddie, A., \& Miller, A. (2001). Beyond rape myths: A more complex view of perceptions of rape victims. Sex Roles, 45(3.4), 139-160. doi:http://dx.doi.org/10.1023/A:1013575209803

Burgess, G. (2007). Assessment of rape-supportive attitudes and beliefs in college men: Development, reliability, and validity of the Rape Attitudes and Beliefs Scale. Journal of Interpersonal Violence, 22(8), 973-993. doi:http://dx.doi.org/10.1177/0886260507302993

Burt, M. (1980). Cultural myths and support for rape. Journal of Personality and Social Psychology, 38(2), 221-230. doi:http://dx.doi.org/10.1037/0022-3514.38.2.217

Cahill, A. (2001). Rethinking rape. Ithaca, NY: Cornell University Press.

Campbell, R., Dworkin, E., \& Cabral, G. (2009). An ecological model of the impact of sexual assault on women's mental health. Trauma, Violence, \& Abuse, 10(3), 225236. doi:http://dx.doi.org/10.1177/1524838009334456

Chiroro, P., Bohner, G., Viki, G., \& Jarvis, C. (2004). Rape myth acceptance and rape proclivity: Expected dominance versus expected arousal as mediators in acquaintance rape situations. Journal of Interpersonal Violence, 19, 427-442. doi:http://dx.doi.org/10.1177/0886260503262081 
Crawford, E., Wright, M., \& Birchmeier, Z. (2008). Drug-facilitated sexual assault: College women's risk perception and behavioral choices. Journal of American College Health, 57(3), 261-272. doi:http://dx.doi.org/10.3200/JACH.57.3.261-272

Danis, F. (2003). Social work response to domestic violence: Encouraging news from a new look. Affilia, 18(2), 177-191. doi:http://dx.doi.org/10.1177/0886109903251407

Deming, M., Covan, E., Swan, S., \& Billings, D. (2013). Exploring rape myths, gendered norms, group processing and the social context of rape among college women: A qualitative analysis. Violence Against Women, 19(4), 465-485. doi:http://dx.doi.org/10.1177/1077801213487044

Duran, M., Moya, M., Megias, J., \& Viki, G. (2010). Social perception of rape victims in dating and married relationships: The role of perpetrator's benevolent sexism. Sex Roles, 62, 505-519. doi:http://dx.doi.org/10.1007/s11199-009-9676-7

Edwards, K., Turchik, J., Dardis, C., Reynolds, N., \& Gidycz, C. (2011). Rape myths: History, individual and institutional-level presence, and implications for change. Sex Roles, 65, 761-773. doi:http://dx.doi.org/10.1007/s11199-011-9943-2

Estrich, S. (1987). Real rape. Cambridge, MA: Harvard University Press.

Finch, E., \& Munro, V. (2007). The demon drink and the demonized woman: Sociosexual stereotypes and responsibility attribution in rape trials involving intoxicants. Social and Legal Studies, 16(4), 591-614. doi:http://dx.doi.org/10.1177/0964663907082737

Gerger, H., Kley, H., Bohner, G., \& Siebler, F. (2007). Acceptance of modern myths about sexual aggression scale: Development and validation in German and English. Aggressive Behavior, 33, 422-430. doi:http://dx.doi.org/10.1002/ab.20195

Grubb, A., \& Harrower, J. (2008). Attribution of blame in cases of rape: An analysis of participant gender, type of rape and perceived similarity to victim. Aggression and Violent Behavior, 13, 396-405. doi:http://dx.doi.org/10.1016/j.avb.2008.06.006

Hayes, R. M., Lorenz, K., \& Bell, K. A. (2013). Victim blaming others: Rape myth acceptance and the just world belief. Feminist Criminology, 8(3), 202-220. doi:http://dx.doi.org/10.1177/1557085113484788

Hayes-Smith, R., \& Levett, L. (2010). Student perceptions of sexual assault resources and prevalence of rape myth attitudes. Feminist Criminology, 5(4), 335-354. doi:http://dx.doi.org/10.1177/1557085110387581

Heath, N., Lynch, S., Fritch, A., \& Wong, M. (2013). Rape myth acceptance impacts the reporting of rape to the police. A study of incarcerated women. Violence Against Women, 19(9), 1065-1078. doi:http://dx.doi.org/10.1177/1077801213501841

Hinck, S., \& Thomas, R. (1999). Rape myth acceptance in college students: How far have we come? Sex Roles, 40(9.10), 815-832. 
Kahlor, L., \& Morrison, D. (2007). Television viewing and rape myth acceptance among college women. Sex Roles, 56, 729-739. doi:http://dx.doi.org/10.1007/s11199-007$\underline{9232-2}$

King, L., \& Roberts, J. (2011). Traditional gender role and rape myth acceptance: From the countryside to the big city. Women and Criminal Justice, 21(1), 1-20. doi:http://dx.doi.org/10.1080/08974454.2011.536045

Krebs, C., Lindquist, C., Warner, T., Fisher, B., \& Martin, S. (2007). Campus sexual assault survey. Retrieved from https://www.ncjrs.gov/pdffiles1/nij/grants/221153.pdf

Lawyer, S., Resnick, H., Bakanic, V., Burkett, T., \& Kilpatrick, D. (2010). Forcible, drug- facilitated, and incapacitated rape and sexual assault among undergraduate women. Journal of American College Health, 58(5), 453-460. doi:http://dx.doi.org/10.1080/07448480903540515

Lonsway, K., \& Fitzgerald, L. (1994). Attitudinal antecedents of rape myth acceptance: A theoretical and empirical reexamination. Journal of Personality and Social Psychology, 68(4), 704-711. doi:http://dx.doi.org/10.1037/0022-3514.68.4.704

McMahon, S. (2010). Rape myth beliefs and bystander attitudes among incoming college students. Journal of American College Health, 59(1), 3-11. doi:http://dx.doi.org/10.1080/07448481.2010.483715

McMahon, S., \& Schwartz, R. (2011). A review of rape in the social work literature: A call to action. Affilia: Journal of Women \& Social Work, 26(3), 250-263. doi:http://dx.doi.org/10.1177/0886109911417683

National Institute of Justice [NIJ]. (2000). The sexual victimization of college women. Retrieved from https://www.ncjrs.gov/pdffiles1/nij/182369.pdf

NIJ. (2007). Campus sexual assault study: Final report. Retrieved from https://www.ncjrs.gov/pdffiles1/nij/grants/221153.pdf

NIJ. (2008). Sexual assault on campus. Retrieved from http://www.nij.gov/topics/crime/rape-sexual-violence/campus/pages/knowattacker.aspx

Perilloux, C., Duntley, J. D., \& Buss, D. M. (2012). The costs of rape. Archives of Sexual Behavior, 41(5), 1099-1106. doi:http://dx.doi.org/10.1007/s10508-011-9863-9

Peterson, Z., \& Muehlenhard, C. (2004). Was it rape? The function of women's rape myth acceptance and definitions of sex in labeling their own experiences. Sex Roles, 51(3.4), 129-144. doi:http://dx.doi.org/10.1023/B:SERS.0000037758.95376.00

Postma, R., Bicanic, I., Vaart, H., \& Laan, E. (2013). Pelvic floor muscle problems mediate sexual problems in young adult rape victims. The Journal of Sexual Medicine, 10(8), 1978-1987. doi:http://dx.doi.org/10.1111/jsm.12196

Rice, N., Robone, S., \& Smith, P. (2011). Analysis of the validity of the vignette approach to correct for heterogeneity in reporting health system responsiveness. The 
European Journal of Health Economics, 12(2), 141-162. doi:http://dx.doi.org/10.1007/s10198-010-0235-5

Ryan, K. (2011). The role of rape myths and sexual scripts: The social construction of rape. Sex Roles, 65, 774-782. doi:http://dx.doi.org/10.1007/s11199-011-0033-2

Shin, S. (2005). Rape, color and global feminism: A converging consciousness. In E. Buchwald, P. Fletcher, \& M Roth. (Eds.), Transforming rape culture (pp. 47-56). Minneapolis, MN: Milkweed Editions.

Ullman, S. E., \& Peter-Hagene, L. (2014). Social reactions to sexual assault disclosure, coping, perceived control, and PTSD symptoms in sexual assault victims. Journal of Community Psychology, 42(4), 495-508. doi:http://dx.doi.org/10.1002/jcop.21624

U.S. Department of Justice [USDOJ]. (2011, 2013). Female victims of sexual violence, 1994-2010. Retrieved from http://www.bjs.gov/content/pub/pdf/fvsv9410.pdf

USDOJ. (2012). Attorney General Eric Holder announces revisions to Uniform Crime Report's Definition of Rape. Retrieved from http://www.justice.gov/opa/pr/attorneygeneral-eric-older-announces-revisions-uniform- crime-report-s-definition-rape

USDOJ. (2014a). Criminal Victimization, 2013. Retrieved from http://www.bjs.gov/content/pub/pdf/cv13.pdf

USDOJ. (2014b). Rape and sexual assault victimization among college-age females age females, 1994-2013. Retrieved from http://www.bjs.gov/content/pub/pdf/rsavcaf9513.pdf

USDOJ. (2014c). What is sexual assault? Retrieved from http://www.justice.gov/ovw/sexual-assault

Vanderwoerd, J. (2009). Experiences of sexual coercion, awareness of services, and acceptance of rape myths among students in rural colleges. Rural Social Work and Community Practice, 14(1), 17-28.

Walsh, S. (2015). Addressing sexual violence and rape culture: Issues and interventions targeting boys and men. Agenda, 29(3), 134-141.

Ward, C. (1995). Attitudes toward rape: Feminist and social psychological perspectives. Thousand Oaks, CA: Sage.

White House Council on Women and Girls. (2014). Rape and sexual assault: A renewed call to action. Retrieved from http://iaclea.org/visitors/about/documents/WhiteHouseCouncil_sexual assault report 1-21-14.pdf

Yuan, N. P., Koss, M. P., \& Stone, M. (2006). The psychological consequences of sexual trauma. National On-line Resource Center on Violence Against Women. Retrieved from http://www.vawnet.org/applied-research-papers/printdocument.php?doc_id=349 
Zillmann, D., \& Weaver, J. B. (1989). Pornography and sexual callousness toward women. In D. Zillmann \& J. Bryant (Eds.), Pornography: Research advances \& policy considerations (pp. 95-125). Hillsdale, NJ: Lawrence Erlbaum.

Zinzow, H. M., Amstadter, A. B., McCauley, J. L., Ruggiero, K. J., Resnick, H. S., \& Kilpatrick, D. G. (2011). Self-rated health in relation to rape and mental health disorders in a national sample of college women. Journal of American College Health, 59(7), 588-594. doi:http://dx.doi.org/10.1080/07448481.2010.520175

\section{Author note:}

Address correspondence to: Adrienne Baldwin-White, School of Social Work, Arizona State University, University Center, 411 N. Central Avenue, Suite 800, Phoenix, AZ 85004, Adrienne.Baldwin@asu.edu 